\title{
AL-QUR'AN AS A TRANSENDENT COMMUNICATION MEDIA
}

\author{
Arina Rahmatika \\ STAI Sunan Pandanaran Yogyakarta \\ arina.eljawie@gmail.com
}

\begin{abstract}
This research proves that human communication with God is a transcendent communication process that is important for human life and its success cannot be measured. Al Quran in this case as evidence of transcendent communication. The Qur'an is a medium of communication in the form of the word of God which was revealed to the Prophet Muhammad SAW for all humans through the angel Gabriel. While communication is the process of sending messages or information from the communicator to the communicant and then generating feedback. God in this context as a transcendent communicator, then his message is written in the Qur'an itself and humans as communicants and the Prophet is the one who delivers the news.
\end{abstract}

\section{Keywords: Al-Qur'an, media, Transcendent Communication}

\section{INTRODUCTION}

Humans are social creatures who need communication in their lives. Not only communication with fellow humans, but humans also communicate with the supernatural (transcendent) even in the Qur'an humans are commanded to communicate with their God. ${ }^{1}$

Islam as a religion believes that Allah is God, while the Messenger of Allah is His messenger in charge of conveying the Qur'an. The Qur'an is here to convey the word of God to humans which was revealed through the Prophet Muhammad SAW through the angel Gabriel, as stated in the An Najm:10.

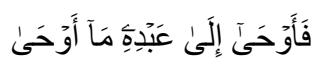

Meaning: Then he conveyed to His servant (Muhammad) what Allah had revealed.

The Qur'an is also the greatest miracle in human history1 because the Qur'an contains a detailed autobiography of Allah in the form of what, who and how Allah is

1 M. Djarot S, Komunikasi Quraniyah: Tadabbur untuk Pemelihara Jiwa, (Bandung: Pustaka Islamika, 2006), p. 32. 
the majority in the discussion. So don't be surprised if the Quran is a kind of verbalistic media form (writing, illustration and sound). ${ }^{2}$

Not only that, the Qur'an also tells a message that builds human survival through the Qur'an which is a means of communicating God to humans to instill understanding, teach, give instructions, explain, invite and convey revelation. ${ }^{3}$ As stated in Ash-Shuraa: 51.

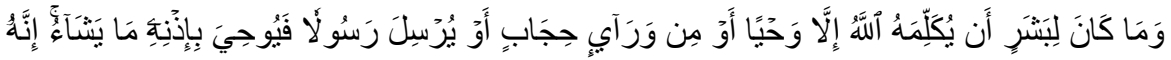

$$
\begin{aligned}
& \text { عَلِيٌ حَكَيِّ }
\end{aligned}
$$

Meaning: And it is not possible for any human being that Allah can speak to him except by means of revelation or behind a veil or by sending a messenger (angel) and then it is revealed to him with His permission what He wills. Verily, He is Most High, Most Wise.

Seeing how important the Qur'an is for humans and Muslims in particular, communication as a science is here to prove the validity of the Qur'an as a transcendent communication medium.

\section{DEFINING TRANSENDENT COMMUNICATION}

Linguistically, communication comes from the Latin word communis which means "same", communico, communication, or communicare which means "to make the same" (to make common). ${ }^{4}$ Then communication can be interpreted as the process of equating information or messages from the communicator to the communicant. In the process of communication, it can be through various media such as sound, books, or other media that can deliver the message.

While transcendence is the art of religion (the core of religion) and is the core of the values of religious teachings that are divine in nature and serve as guidelines for human life. Meanwhile, according to Kuntowijoyo, transcendence has two functions, namely:

a. Become the basis for humanization and liberation. The purpose of humanization is the close relationship between charity and faith. Meanwhile, the meaning of liberation is that humans always focus on God.

2 Ibid., p. 23.

3 Ibid., p. 71.

4 Mulyana, Deddy, Nuansa-Nuansa Komunikasi: Meneropong Politik dan Budaya Komunikasi Masyarakat Kontemporer. Bandung: Remaja Rosdakarya, 2009) p. 46. 
So in this case, transcendence will be able to function as a meaning of human life.

b. Become a critique of human civilization. In this case, human civilization is measured based on transcendence (faith). ${ }^{5}$

According to Ahmad Najib Burhani, transcendence means believing in God does not mean forgetting humans. Even though there is faith in God, but there is still actualization to fellow creatures from the relationship with God. ${ }^{6}$ Therefore it can be concluded that transcendence (faith) is the main goal of human life and as a process of humanizing (humanization). ${ }^{7}$

Transcendent communication itself is a new term in communication that has not been widely studied by communication experts. Whereas in communication science, transcendental communication is a form of communication.

According to Padje, transcendental communication is communication with something supernatural, including communication with God or supernatural or beyond mere worldly reality. ${ }^{8}$ Meanwhile, according to Mulyana, transcendent communication is communication that involves humans and God. ${ }^{9}$ Human communication with God is a communication process that needs to be studied more deeply in a concrete and comprehensive manner and is an important form of communication for humans because human success in doing so is immeasurable.

Sudut pandang komunikasi transenden yang seperti itu maka Islam mempunyai pedoman hidup yang diturunkan Allah untuk menjawab persoalan yang sesuai dengan umat manusia berupa al Qur'an. ${ }^{7}$ God is a transcendent being who "No sight can see Him (6:103) and there is nothing like Him (42:11)".10

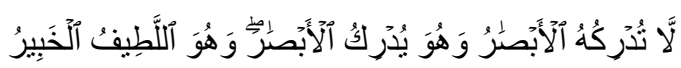

Meaning: He cannot be reached by sight, while He can see everything that is visible; And He is the Most Subtle, the All-Knowing.

${ }^{5}$ Kuntowijoyo, Dinamika Sejarah Umat Islam Indonesia, (Yogyakarta: Mata Bangsa), p. 171

${ }^{6}$ Ahmad Najib Burhani, Islam Dinamis, p. 15.

7 Thohir, Umar Faruq. Etika Islam dan transformasi global. CV. Pustaka Ilmu Group, 2013.

${ }^{8}$ Padje, Gud Recht Hayat. Komunikasi Kontemporer: Strategi, Konsepsi, dan Sejarah. Kupang: Universitas PGRI, 2008. P.20

${ }^{9}$ Deddy Mulyana, Nuansa-Nuansa Komunikasi, p.49.

${ }^{10}$ Poedjawiyatna, Filsafat Tingkah Laku-Etika, (Yogyakarta: Kanisius, 1992), p. 25. 


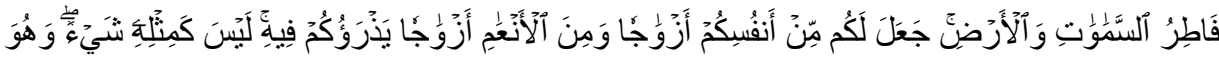

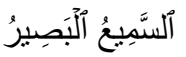

Meaning: (He is) the Creator of the heavens and the earth. He made for you from your own kind pairs and pairs of livestock (also), He made you breed in that way. There is nothing like Him, and He is the All-Hearing and Seeing.

With the existence of a transcendent substance whose existence is outside of humans, namely God. So the way to get life guidance from Allah is to understand the content and intentions contained in the transcendental Qur'an. Although the contents of the Qur'an refer to actual events according to their historical context.11

\section{ELEMENTS OF TRANSENDENT COMMUNICATION}

Islam came to perfect human morals, so that change and transformation into eternity in Islam. Meanwhile, according to Kuntowijoyo, humanization (amar makruf), liberation (nahi munkar), and transcendence (tukminu billah) are steps towards transformation. So when confronting the Qur'an with social reality or vice versa, the Qur'an will be placed as a source for the formation of social constructions. ${ }^{12}$ Even a number of values in the Koran as material to explore the reality of communication. ${ }^{13}$

The communication paradigm proposed by Harold Lasswell in 1960, in his work The Structure and Function of Communication in Society, explains that a good way to explain communication is to answer the question Who says what in which channel to who with what effect? From that question Laswell shows that there are 5 elements of communication, namely communicators, communicants, messages, media and effects.

\section{God as Communicator}

The communicator is someone who gives a message to the communicant. The communicator must also be able to know and understand what he conveys to the communicant because the message does not arrive if the communicator does not

${ }^{11}$ Koentowijoyo, Paradigma Islam Intrepretasi untuk Aksi, (Bandung: Mizan, 1998), p. 29.

12 Iswandi Syahputra, Komunikasi Propetik: Konsep dan Pendekatan, (Bandung: Simbiosa rekatama media, 2007) p. 130.

13 Ibid., p.138. 
understand what he wants to convey. In transcendent communication, God is the communicator.

Why should God? Because the source and speaker in the Qur'an is Allah. So that the emergence of the Qur'an provides an understanding to perfect the basic knowledge of God that arises from within humans. ${ }^{14}$ And because the Qur'an has a purpose about God, Allah will protect the Qur'an (Al kahfi:1 and al-hijr 9).15

On the other hand, the universe and its processes do not run by itself without connecting it to a higher being. The Qur'an refers to this as "belief and awareness of the unseen." But this unseen becomes "real" through revelation. God's presence can be felt by those who do contemplation, namely "people who fear the Most Merciful in a state of unseen and face with a repentant heart." (50:33).

So how does God communicate with humans?

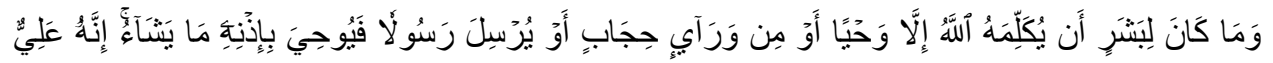

Meaning: And it is not possible for any human being that Allah can speak to him except by means of revelation or behind a veil or by sending a messenger (angel) and then it is revealed to him with His permission what He wills. Verily, He is Most High, Most Wise.

From the Qur'an, Surah Ash-Shura: 51 above, three ways of communication of revelation are put forward, namely (a) through the Qur'an, a way of communication beyond the reach of human consciousness, (b) through behind the scenes, in the sense that the apostle heard certain speeches but did not hear them. able to see the speaker, and (c) through a messenger, namely the face-to-face communication process between the apostle and the angel. Of the three ways of communication, it boils down to the Qur'an, even for anyone who reads the Qur'an, even if they do not understand its meaning, it is counted as worship and gets a reward.

14 Muhammad Husaini Ismail, Kebenaran Mutlak: Agama, Tuhan dan Hakikat Manusia. (Jakarta: Sahara Publisher, 2006), p. 330.

15 Ibid., p.333. 
The Qur'an is the word of God given to humans to serve as a straight guide for both personal and social life (2: 185). If this path to God is used by mankind, it will show God's role as Creator and His role as Judge. ${ }^{16}$

\section{Humans as Communicants}

\section{a. Al Quran For Humans}

The communicant is the recipient of the message. Communication is said to be successful if the message conveyed by the communicator can be well received by the communicant. The communicant in transcendent communication is human. That's because humans are God's creations that have a spirit $(15: 29 ; 38: 72 ; 32: 9){ }^{17}$

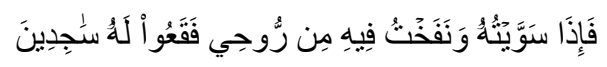

Meaning: So when I have perfected the event, and have breathed into it My spirit (creation), then submit to it in prostration..

In the life of the world, humans are commanded to be caliphs on earth. With this task, humans as representatives of God are given the free choice to make all efforts that need to be made to protect the earth. ${ }^{18}$ Then in the hereafter, humans will be responsible for all their actions while living in this world in front of God alone. Thus, life that only once will determine the fate of humans in the hereafter.

Al-Quran is present as a guide to save humans in the hereafter. But not only that, the purpose of humans was also created to serve God and to thank Him. ${ }^{19}$ The form of human gratitude and worship to God is not for the sake of God, but for the benefit of man himself, as stated in Al Mukmin: $115 .^{20}$

In addition, humans were created with the aim of building a social order ${ }^{21}$ that can continue on earth based on the principles of justice and ethics.22 The Qur'an's purpose of an ethical order is reflected in its vehement rejection of economic inequality and social injustice, both the abuse of girls, orphans, and

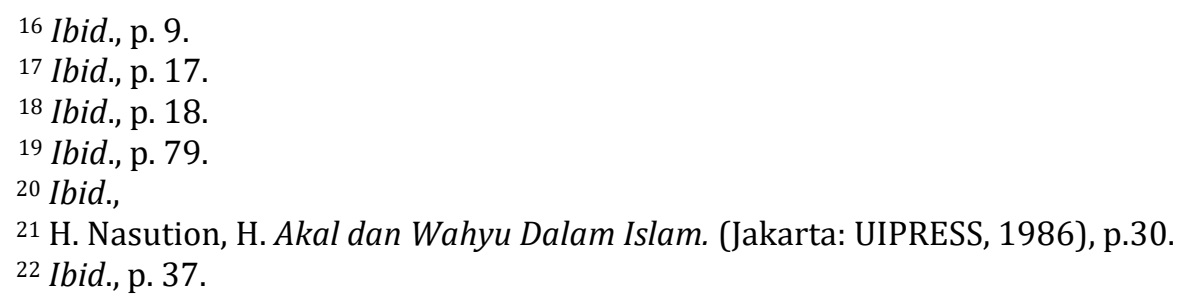


women. ${ }^{23}$ So the Qur'an teaches that the struggle for justice in society is part of protecting the earth.

b. Al Quran for Prophet Muhammad

God's direction to humans is assisted by figures who are able to convey what God wants humans to do, they are prophets and apostles. Prophets and Apostles are human beings sent by Allah to convey His message, whether stated or not in the Qur'an (40:78; 4:164).

So the meaning of the word prophet has a transcendent meaning with the term annabiy or bearer of news / information. ${ }^{24}$ The prophets and apostles are examples of God's journalists because their job is to carry the information needed by their people.

The word of the apostle means God's message to humans ${ }^{25}$ and is a form of authenticity of the Koran. The message conveyed is not only local, but has a universal meaning that must be believed and followed by all humans. Through this message, human awareness will increase so that humans are expected to be able to clearly see God's message. ${ }^{26}$

On the other hand, the Quran is proof of the truth of the prophet Muhammad. Muhammad as the closing prophet and the Qur'an as the final revelation, explain that it is the heavy responsibility of Muslims to carry forward the message of Allah. ${ }^{27}$

\section{Devils and Demons As Noise}

Satan as a form of evil as opposed to good, is included in the discussion material about human actions individually and collectively. As mentioned earlier, Satan is an anti-human force. The principle of evil that the Qur'an personifies as a devil or devil, even though the second personification is weaker than the first. The Qur'an, especially in the Makiyah letters, repeatedly mentions Satan in the plural (syayâthîn), which sometimes refers metaphorically to humans as well. The Qur'an guarantees that the devil's temptations will not work against those who believe and

\footnotetext{
23 Ibid.

${ }^{24}$ Iswandi Syahputra, Komunikasi Propetik, p. 160.

25 Ibid., p. 82.

26 Ibid., p. 80.

27 Ibid., p. 81.
} 
submit to God: "Verily Satan has no power over those who believe and those who submit to their Lord".

To deal with Satan as an evil force, humans need to develop taqwa behavior (an effort to protect one's self against the harmful or bad consequences of one's actions). ${ }^{28}$ Satan is an anti-human force, not an anti-God. His job is to trick people into slipping from the straight path. Taqwa provides stability to humans in determining their moral choices.

\section{AL-QURAN AS A MEDIUM OF COMMUNICATION}

\section{a. Communication media}

The communication process is usually conveyed by the communicator to the communicant by using the media. According to Cangara, media is a tool or means used to convey messages from communicators to the public, so that indirectly the media is a means of communication and one of the forums for disseminating information. ${ }^{29}$

Likewise with the Koran. The Qur'an is a tool or means used by Allah to convey messages to humans and jinn. The message is the teachings that are in the Koran. It was later emphasized by Fahrurrozi that the Qur'an is a form of Allah's communication to His creatures which is immortalized in the text (writing) even the Qur'an as a holy book can be categorized as one type of print mass media.

Print media is a media that prioritizes its function as a medium for delivering information, so print media consists of sheets with the main function of providing information. Print media is also a document for everything that is said and recorded events in the form of words, pictures, photos, and so on. ${ }^{30}$

Along with the development of technology, the Koran also has various forms of media. Such as Visual Media or Visual Media where to receive messages conveyed using the sense of sight such as calligraphy of the Koran. Audio media in the form of receiving messages conveyed using the sense of hearing, such as recordings of reading the Koran and Audio-Visual media or communication media that can access

28 Ibid., p. 29.

29 Hafied Cangara, Pengantar Ilmu Komunikasi, (Rajawali Press, 2003), p.134. p.99.

30 Elvinaro Ardianto, Pubic Realations Praktis. (Jakarta: Widya Padjajaran, 2009), 
the information conveyed by the Koran, using the senses of sight and hearing at the same time.

\section{b. Media Characteristics of the Qur'an}

There are several characteristics of the Qur'an which is the medium that Allah created:

1. 1. Aspects of beauty and accuracy of the editor

Islam was revealed in Arabia as a continuation of the previous and civilized religion that was already advanced at that time. ${ }^{31}$ So the Qur'an which was also revealed in Arabic and in Arabic as a very broad, rich and complete approach and has a spiritualistic dimension, so that the information used is spiritually charged so that it becomes easy to understand and is in line with the objectives of the Qur'an. ${ }^{32}$ Even the editorial composition of the Koran reaches the highest peak of Arabic literature, so that the Koran is designated as a work of Islamic art and the beauty of the Arabic language in the Koran is obtained through feelings not reason.

2. Aspects of occult news

Aspects of occult news about previous history to be learned lessons in the past or in the future. For this reason, the Qur'an is always realistic and naturalistic towards nature so that it becomes a reference for various facts. So do not be surprised if the reader becomes familiar with these stories, and can take the moral message in them.

3. Aspects of scientific cues

Many scientific theories that exist in the Qur'an prove that Allah is the creator of the Qur'an and all living things.

The combination of these elements causes the reader or listener of the Qur'an to be impressed by its beauty and perfection.33 Apart from being determined by the teachings of the Qur'an, Islamic art is also "Qur'anic" in the sense that the holy book of the Qur'an is the main and highest model for creativity and aesthetic production. The Qur'an is declared "the first work of art

${ }^{31}$ M. Djarot S, Komunikasi Quraniyah, p. 39.

32 Ibid., p.38.

33 Al-Faruqi, Ismail Raji. Seni Tauhid. Terj. Hartono Hadikusumo. (Yogyakarta: Bentang, 1999), p. 14. 
in Islam" does not mean that the Qur'an is considered a literary genius of the Prophet Muhammad. On the other hand, Muslims believe that the content and form are divine which represent the infinite patterns of Islamic art. The Qur'an is the most perfect example of the infinite pattern that influences all subsequent creations in the arts of literature, fine arts (both decorative and architectural) even the art of sound and motion art.. ${ }^{34}$

\section{c. The Role of the Quran as a Communication Media}

The Koran also has the same function as the mass media, such as the information function, education function, social criticism function, and social control function. Burhan Bungin in his book sociology of communication says that the media have several roles such as::

1. To educate

Al-Quran is dynamic and as a function of inspiration and motivation for social construction. 35

2. To inform

The importance of public awareness to obtain information through the Qur'anic approach is a method of interconnecting holy verses with current reality. ${ }^{36}$ In the Qur'an, Allah wants to emphasize that Allah as a source of information has the obligation to disseminate information to humans through the intermediary of the prophet or the bearer of information. And confirms that humans are weak creatures without news/information. And without information, humans will be low in dignity. ${ }^{37}$ So that the Qur'an is present to be a giver of information from Allah to all humans. ${ }^{38}$

3. 3. Cultural institutions

The Qur'an is a guarantee towards a beginning, honorable life, etc. $(21: 10)(43: 44)^{39}$ Play a role in protecting society from culture that can

\footnotetext{
${ }^{34}$ Ibid., p.17.

35 Iswandi Syahputra, Komunikasi Propetik, p. 145.

${ }^{36}$ Ibid., p.160.

37 Ibid.

${ }^{38}$ M. Djarot S, Komunikasi Quraniyah, p. 34.

${ }^{39}$ Ibid., p.30.
} 
damage morals and social life. The Koran is a heavy word because it contains a collection of Allah's words that contain the risk of testing or trials. ${ }^{40}$

\section{CONCLUSION}

Islam as a perfect religion with the Qur'an as evidence of a transcendent communication between God and humans. In this case, transcendent communication in the form of the Qur'an is a means of communication for Muslims with Allah to ask for guidelines for life that answer life's problems..

Transcendent communication is also in accordance with the elements of communication, namely communicators, communicants, messages, media and effects.

The Qur'an is a form of communication media of Allah to His creatures which is enshrined in text (writing) even the Qur'an as a holy book can be categorized as one type of printed mass media that has information functions, education functions, social criticism functions and functions. social control.

\section{REFERENCES}

Ahmad Najib Burhani, Islam Dinamis: Menggugat Peran Agama, Membongkar Doktrin yang Membeku, Jakarta: PT. Kompas Media Nusantara, 2001

Al-Faruqi, Ismail Raji. Seni Tauhid. Translated by Hartono Hadikusumo, Yogyakarta: Bentang, 1999

Dinamika Sejarah Umat Islam Indonesia, Yogyakarta: Mata Bangsa

Elvinaro Ardianto, Pubic Realations Praktis, Jakarta: Widya Padjajaran, 2009

Fazlurrahman, Tema-Tema Pokok al-Qur'an, Bandung: Mizan, 2017

H. Nasution, H. Akal dan Wahyu Dalam Islam, Jakarta: UIPRESS, 1986

Hafied Cangara, Pengantar Ilmu Komunikasi, Rajawali Press, 2003

Iswandi Syahputra, Komunikasi Propetik: Konsep dan Pendekatan, Bandung: Simbiosa rekatama media, 2007

Koentowijoyo, Paradigma Islam Intrepretasi untuk Aksi, Bandung: Mizan, 1998

Kuntowijoyo, Kuntowijoyo, Muslim Tanpa Masjid, Bandung: Mizan, 2001

M. Djarot S, Komunikasi Quraniyah: Tadabbur untuk Pemelihara Jiwa, Bandung: Pustaka Islamika, 2006

Muhammad Husaini Ismail, Kebenaran Mutlak: Agama, Tuhan dan Hakikat Manusia. Jakarta: Sahara Publisher, 2006

Mulyana, Deddy. Nuansa-Nuansa Komunikasi: Meneropong Politik dan Budaya Komunikasi Masyarakat Kontemporer. Bandung: Remaja Rosdakarya, 2009

40 Ibid., p.31. 
QAULAN, Vol. 2, No.2, Desember 2021

Arina Rahmatika, Al-Qur'an As A Trancendent....

Padje, Gud Recht Hayat. Komunikasi Kontemporer: Strategi, Konsepsi, dan Sejarah. Kupang: Universitas PGRI, 2008.

Poedjawiyatna, Filsafat Tingkah Laku-Etika, Yogyakarta: Kanisius, 1992

Rusdi Hamka dan Rafiq, Islam dan Era Informasi. Jakarta: Pustaka Panji Mas, 1989

Thohir, Umar Faruq. Etika Islam dan transformasi global. CV. Pustaka Ilmu Group, 2013. 